九州大学学術情報リポジトリ

Kyushu University Institutional Repository

Optimum Medium Components and Culture Conditions for the Production of Intra- and Extra-cellular Pullulanase by Aerobacter aerogenes

Ohba, Ri ichiro

Laboratory of Microbial Technology, Faculty of Agriculture, Kyushu University

Ueda, Se inosuke

Laboratory of Microbial Technology, Faculty of Agriculture, Kyushu University

https://doi.org/10.5109/23725

出版情報：九州大学大学院農学研究院紀要. 25 (2/3)，pp. 135-151，1980-11. Kyushu University バージョン：

権利関係 : 
J. Fac. Agr.. Kyushu Univ., 25 (2 • 3) 135-151 (1980)

\title{
Optimum Medium Components and Culture Conditions for the Production of Intra- and Extra-cellular Pullulanase by Aerobacter aerogenes
}

\author{
Riichiro Ohba and Seinosuke Ueda \\ Laboratory of Microbial Technology, Faculty of Agriculture, \\ Kyushu University 46-09, Fukuoka 812 \\ (Received July 31,1980)
}

\begin{abstract}
Culture conditions for pullulanase production by Aerobacter aerogenes RS-1 were found to be quite different from those of other strains of the same species reported earlier. Among the components investigated, $\left(\mathrm{NH}_{4}\right)_{2} \mathrm{SO}_{4}$ and $\mathrm{NH}_{4} \mathrm{Cl}$ produced pullulanase mostly inside the cells and the enzyme was not released from them. $\mathrm{CH}_{3} \mathrm{COONH}_{4}$ was the most effective nitrogen source for the production of extracellular pullulanase. Liquefied potato starch was found to be the most suitable carbon source in both cases of the intra- and extra-cellular pullulanase production. Mono- and di-saccharides could hardly produce pullulanase which may be an "induced enzyme". $\mathrm{KC} 1$ was not necessary for pullulanase production. $\mathrm{CaCO}_{3}$ was an essential component for $\mathrm{pH}$-control in the early stage of intracellular enzyme production. Peptone, $\mathrm{MgSO}_{4} \cdot 7 \mathrm{H}_{2} \mathrm{O}$ and $\mathrm{FeSO}_{4} \cdot 7 \mathrm{H}_{2} \mathrm{O}$ were found to play considerably important roles for pullulanase production and it became evident that the absence of each of them caused a decrease of 20-80\% of pullulanase production. $\mathrm{K}_{2} \mathrm{HPO}_{4}$ was the most important component since the bacterial growth was nil without it and consequently pullulanase could not be produced. Under optimum culture conditions, the periods for maximum intra- and extra-cellular pullulanase production were 48 and $96 \mathrm{hr}$ respectively. Extracellular pullulanase production started later than intracellular one and then intracellular pullulanase began to secrete from cells into culture broth.
\end{abstract}

\section{INTRODUCTION}

The enzymes which hydrolyze starch are represented by a-amylase, $\beta-$ amylase and glucoamylase. They have been investigated in detail for a long time. Afterward isoamylase, containing R-enzyme, (EC 3. 2. 1. 9) was first found from yeast (Kobayashi and Maruo, 1949; Maruo and Kobayashi, 1951) and broad bean (Hobson et al., 1951). The enzyme which hydrolyzes a-l. 6glucosidic linkages has attracted special interest recently.

Pullulanase (EC 3.2.1.41, pullulan 6-glucanohydrolase) is an enzyme which hydrolyzes a-l. 6-glucosidic linkages not only in starch but also in pullulan (a kind of polysaccharide, Ueda et al., 1963), being named "debranching enzyme". Starch is hydrolyzed to amylose by an end-mechanism of action of pullulanase and pullulan is also cleaved at random finally to maltotriose (Ohba and Ueda, 1975). Direct production of maltose and maltotriose from starch and pullulan by an immobilized multienzyme of pullulanase and $\beta$-amylase has been at- 
tempted (Ohba et al., 1978; Ohba and Ueda, 1980).

Since Wallenfels and Rached (1966) obtained crystalline intracellular pullulanase from Aerobacter aerogenes, substrate specificity (Abdullah et al., 1966; Abdullah and French, 1970), mechanism of action (Wallenfels et al., 1969; Drummond et al., 1969; Ohba and Ueda, 1975), molecular weight (Wallenfels et al., 1969; Eisele et al., 1972; Mercier et al., 1972; Ohba and Ueda, 1973) etc. of intracellular pullulanase have gradually been studied by various workers. With regard to extracellular pullulanase, the authors (Ueda and Ohba, 1972; Ohba and Ueda, 1975) reported some chemical and enzymatic properties using crystalline enzyme.

Wallenfels et al. (1966) have reported on the mode of pullulanase formation from $A$. aerogenes which distinctly produced intra- and extra-cellular pullulanase by using maltose and glucose as carbon source. A strain of our $A$. aerogenes differed extremely in the mode of pullulanase formation from another one. That is, when $\left(\mathrm{NH}_{4}\right)_{2} \mathrm{SO}_{4}$ was used as a nitrogen source, enzyme was mainly produced inside the cells but when $\mathrm{CH}_{3} \mathrm{COONH}_{4}$ was used instead of $\left(\mathrm{NH}_{4}\right)_{2} \mathrm{SO}_{4}$, enzyme was mainly produced to the culture broth (Fujio et al., 1970; Ueda and Ohba, 1972; Ohba and Ueda, 1973). However, it is required to investigate the effects of other components, their concentration and $\mathrm{pH}$ of the medium, in order to have a clear idea about this interesting mechanism of intra- and extra-cellular enzyme production. The present paper describes the effects of various medium components and the most suitable culture condition for the production of both intra- and extra-cellular pullulanase.

\section{MATERIALS AND METHODS}

\section{Microorganism}

Aerobacter aerogenes RS-1 (a mutant of A. aerogenes No. 105) which had been isolated and preserved in the authors' laboratory was used for pullulanase production.

\section{Media and culture methods}

The composition of slant agar medium for stock culture and precultivation was reported in the previous paper (Ueda and Ohba, 1972). The basal media, which were used conventionally by the authors, are listed in Table 1. A-medium was used for the production of intracellular pullulanase and B-medium for that of extracellular one. Table 2 shows the media used by Wallenfels et al. (1966) for the intra- and extra-cellular pullulanase production from A. aerogenes.

A loopful of the microorganism from a precultivated slant was inoculated into $100 \mathrm{ml}$ medium contained in a $500 \mathrm{ml}$ Erlenmeyer flask and incubated at $30^{\circ} \mathrm{C}$ on a reciprocal shaker. Pullulanase activity was assayed after $48 \mathrm{hr}$ culture in A-medium and $96 \mathrm{hr}$ culture in B-medium unless otherwise specified.

\section{Liquefied starch}

Starch was treated with $\alpha$-amylase (Neospitase K, Nagase Sangyo Ltd.) at $70-80^{\circ} \mathrm{C}$ for partial hydrolysis. The reaction was continued to proceed 
Table 1. Basal medium for pullulanase production. Initial $\mathrm{pH} 7.6$ (both media).

\begin{tabular}{|c|c|}
\hline Component & Content $(\%, w / v)$ \\
\hline \multicolumn{2}{|l|}{ A-medium } \\
\hline $\begin{array}{l}\text { Liquefied potato starch } \\
\left(\mathrm{NH}_{4}\right)_{2} \mathrm{SO}_{4} \\
\mathrm{~K}_{4} \mathrm{HPO}_{2} \\
\mathrm{MSOO}_{4} \cdot 7 \mathrm{H}_{2} \mathrm{O} \\
\mathrm{KCl}\end{array}$ & $\begin{array}{l}1.0 \\
0.8 \\
0.1 \\
0: 0.050\end{array}$ \\
\hline $\begin{array}{l}\text { Peptone } \\
\mathrm{FeSO}{ }_{4} \cdot 7 \mathrm{H}_{2} \mathrm{O}\end{array}$ & $\begin{array}{l}0.05 \\
0.01\end{array}$ \\
\hline $\mathrm{CaCO}_{3}$ & 0.5 \\
\hline \multicolumn{2}{|l|}{ B-medium } \\
\hline $\begin{array}{l}\text { Liquefied potato starch } \\
\mathrm{CH}_{3} \mathrm{COONH} \\
\mathrm{K}_{4} \mathrm{HPO} \cdot \mathrm{HH}_{4} \\
\mathrm{MgSO}_{4} \cdot 7 \mathrm{H}_{2} \mathrm{O} \\
\mathrm{KCl}\end{array}$ & $\begin{array}{l}1.0 \\
0.8 \\
0.1 \\
0.0 .1505\end{array}$ \\
\hline $\begin{array}{l}\text { Peptone } \\
\mathrm{FeSO}{ }_{1} \cdot 7 \mathrm{H}_{2} \mathrm{O}\end{array}$ & $\begin{array}{l}0.05 \\
0.01\end{array}$ \\
\hline
\end{tabular}

Table 2. Medium used by Wallenfels et al. (1966) for pullulanase production. Initial pH 7.2 (both media)

\begin{tabular}{cc}
\hline Component & Content $(\%, \mathrm{w} / \mathrm{v})$ \\
\hline C-medium & 0.8 \\
Maltose & 0.3 \\
$\mathrm{NaNO}_{3}$ & $0: 1$ \\
$\mathrm{~K}_{2} \mathrm{HPO}_{4}$ & 0.05 \\
$\mathrm{MgSO}_{7} \mathrm{H}_{2} \mathrm{O}$ & 0.05 \\
$\mathrm{KCl}$ & 0.001 \\
$\mathrm{FeSO}_{4} \cdot 7 \mathrm{H}_{2} \mathrm{O}$ & \\
\hline D-medium & 0.4 \\
Maltose & 0.4 \\
$\mathrm{Glucose}$ & 0.3 \\
$\mathrm{NaNO}_{3}$ & 0.1 \\
$\mathrm{~K}, \mathrm{HPO}_{4}$ & 0.05 \\
$\mathrm{MgSO}_{4} \cdot 7 \mathrm{H}_{2} \mathrm{O}$ & $0: 05$ \\
$\mathrm{KCl}$ & 0.001 \\
$\mathrm{FeSO}_{4} \cdot 7 \mathrm{H}_{2} \mathrm{O}$ &
\end{tabular}

until the iodine coloration of the solution showed orange-red when a few drops of the reaction mixture was added to $5 \mathrm{ml}$ of $0.001 \mathrm{~N}$ iodine-potassium iodide solution. Then the reaction was stopped by adjusting its $\mathrm{pH}$ at 2.0 with $1 \mathrm{~N} \mathrm{HCl}$. The filtrate obtained after filtration through a Toyo Roshi No. 101 filter paper was used as liquefied starch.

\section{Assay of extracellular pullulanase}

After cultivation, culture broth was centrifuged at $10,000 \mathrm{rpm}$ for $10 \mathrm{~min}$. The activity of the supernatant solution (crude enzyme solution) was used for extracellular pullulanase activity. The activity was expressed as pullulanase units (U) per ml of culture broth. Pullulan, which was prepared from Pullularia pullulans by the procedure of Ueda et al. (1963) with slight modification, was 
used as a substrate of the enzyme reaction.

Pullulanase activity was assayed using a reaction mixture consisting of 1 $\mathrm{ml}$ of $0.5 \%(\mathrm{w} / \mathrm{v})$ pullulan and $0.5 \mathrm{ml}$ of $0.5 \mathrm{M}$ acetate buffer, $\mathrm{pH} 6.0$. After preincubation of the reaction mixture at $40^{\circ} \mathrm{C}$ for a few minutes, $0.5 \mathrm{ml}$ of suitably diluted enzyme solution was added followed by incubation at $40^{\circ} \mathrm{C}$ for 30 min. Reducing sugars released by enzyme action at 10 and $30 \mathrm{~min}$ were then measured by the Somogyi-Nelson method (Nelson, 1944; Somogyi, 1945) with maltotriose (Hayashibara Biochemical Lab. Inc.) as standard. One unit of pullulanase activity is defined as the amount of enzyme that liberates $1 \mu$ mole maltotriose at $40^{\circ} \mathrm{C}$ in $1 \mathrm{hr}$ under the conditions described above.

\section{Assay of intracellular pullulanase activity}

After cultivation, $50 \mathrm{ml}$ of culture broth was centrifuged at $10,000 \mathrm{rpm}$ for $10 \mathrm{~min}$. The cells were collected and washed with water. The washed cells were suspended in $50 \mathrm{ml}$ of water. The activity of the suspension was used as intracellular pullulanase activity. To prevent sedimentation of cells during the enzymatic reaction, a microspatula was put in the test tube $(16 \times 110$ $\mathrm{mm}$ ), and vibration of the shaker (amplitude, $20 \mathrm{~mm}$; frequency, 160 times/ min) caused it to rotate, keeping the cells in suspension. The other procedures were carried out by the same methods as described in the assay of extracellular pullulanase activity.

\section{Determination of cell growth}

Bacterial cell growth was measured using a spectrophotometer, as the optical density (O.D.) at $660 \mathrm{~nm}$ of the culture broth after diluting 20 folds with water. In the case of A-medium (usually containing $\mathrm{CaCO}_{3}$ ), $0.01 \mathrm{~N} \mathrm{HCI}$ was used to dilute instead of water, and residual $\mathrm{CaCO}_{3}$ was fully neutralized.

\section{Determination of residual sugars}

Reducing sugars in each culture broth was determined as glucose equivalent by the Somogyi-Nelson method after hydrolyzing $1 \mathrm{ml}$ of the supernatant with $2 \mathrm{ml}$ of $1 \mathrm{~N} \mathrm{HCl}$ for $3 \mathrm{hr}$ and neutralizing with sodium hydrogen carbonate.

\section{RESULTS AND DISCUSSION}

Comparison of the basal media with media used by Wallenfels et $\boldsymbol{a l}$.

The results of formation of intra- and extra-cellular pullulanase by $\boldsymbol{A}$. aerogenes RS-1 using the basal media (A- and B-media) and the media used by Wallenfels et al. (1966) (C- and D-media) are summarized in Table 3. The intracellular pullulanase production was remarkably increased and extracellular one decreased in the A-medium, and conversely extracellular pullulanase production was significantly increased and intracellular one decreased in the B-medium.

On the other hand, in the C- and D-media, there was no intra- and extra-cellular pullulanase formation and the cells were poorly grown.

Accoring to Wallenfels et al. (1966), their $\boldsymbol{A}$. aerogenes produced both intra- 
Table 3. Comparison of the basal media with the media used by Wallenfels et al.

\begin{tabular}{cccccc}
\hline Medium & $\begin{array}{c}\text { Cultivation } \\
\text { period } \\
\text { (days) }\end{array}$ & Final pH & $\begin{array}{c}\text { Growth } \\
\text { (O.D. at } 660\end{array}$ & & \multicolumn{2}{c}{ Pullulanase activity } \\
\cline { 5 - 6 } & & & & $\begin{array}{c}\text { Intracellular } \\
\text { (U/ml) }\end{array}$ & $\begin{array}{c}\text { Extracellular } \\
\text { (D/ml) }\end{array}$ \\
\hline A & 4 & 9.12 & 9.6 & 33.1 & 1.2 \\
B & 2 & 9.34 & 9.0 & 3.3 & 52.9 \\
C & 4 & 8.91 & 3.2 & 0 & 0.8 \\
D & 2 & 9.08 & $3: 2$ & 0 & 0.7 \\
& 4 & 9.94 & 3.2 & 0 & 0.9 \\
\end{tabular}

and extra-cellular pullulanase in the C-medium and only intracellular one in the D-medium. This investigation revealed that the mode of pullulanase formation by A. aerogenes RS-1 differed from that by bacteria used by Wallenfels et al. (1966), and showed its own characteristics, that is, intra- and extracellular enzyme could not be specifically produced by using carbon sources such as maltose and glucose.

\section{Effect of nitrogen sources in the presence of calcium carbonate}

Inorganic and organic nitrogen compounds $(0.8 \%$, w/v) containing especially ammonium group in most cases were added into the medium. Further, $0.5 \%(\mathrm{w} / \mathrm{v})$ calcium carbonate sterilized in a hot air oven was added into the medium at the time of inoculation. After cultivation for 4 days, the culture broth was assayed.

The results of enzyme production using these nitrogen sources are shown

Table 4. Effect of nitrogen sources on pullulanase production in the presence of $\mathrm{CaCO}_{3}$.

\begin{tabular}{|c|c|c|c|c|}
\hline \multirow{2}{*}{ Nitrogen source } & \multirow{2}{*}{ Final $\mathrm{pH}$} & \multirow{2}{*}{$\begin{array}{c}\text { Growth } \\
\text { (O.D. at } 660 \mathrm{~nm})\end{array}$} & \multicolumn{2}{|c|}{ Pullulanase activity } \\
\hline & & & $\begin{array}{l}\text { Intracellular } \\
(\mathrm{H} / \mathrm{ml})\end{array}$ & $\begin{array}{c}\text { Extracellular } \\
(\mathrm{D} / \mathrm{ml})\end{array}$ \\
\hline$\left(\mathrm{NH}_{4}\right)_{2} \mathrm{SO}_{4}$ & 8.7 & 7.8 & 44. a & 0.9 \\
\hline $\mathrm{NH}_{4} \mathrm{Cl}^{-4}$ & 7.5 & 7.6 & 37. 6 & 0.1 \\
\hline$\left(\mathrm{NH}_{4}\right)_{2} \mathrm{HPO}_{4}$ & 7.7 & 5.8 & 33.0 & $24 ; 4$ \\
\hline$\left(\mathrm{NH}_{4} \mathrm{H}_{2} \mathrm{PO}_{4}\right.$ & 7.6 & 6.2 & $33 ; 7$ & 27.1 \\
\hline$\left(\mathrm{NH}_{4}\right)_{2} \mathrm{C}_{4} \mathrm{H}_{4} \mathrm{O}_{6}$ & 8.9 & 9.0 & 5.8 & 10.8 \\
\hline $\mathrm{CH}_{3} \mathrm{COONH}_{4}$ & 8.9 & 11.2 & 8.5 & 41.0 \\
\hline $\mathrm{HCOONH}_{4}$ & 9.3 & 8.4 & 33. a & 16.0 \\
\hline $\mathrm{NH}_{4} \mathrm{NO}_{3}$ & 8.2 & 10.0 & 8.4 & 0 \\
\hline $\mathrm{FeSO}_{4}\left(\mathrm{NH}_{4}\right)_{2} \mathrm{SO}_{4}$ & 7.8 & 10.8 & 6.1 & 0 \\
\hline $\mathrm{Fe}\left(\mathrm{SO}_{4}\right)_{3}\left(\mathrm{NH}_{4}\right)_{2} \mathrm{SO}_{4}$ & 7.9 & 9.0 & 0 & 6.4 \\
\hline $\mathrm{NH}_{4} \mathrm{H}_{2} \mathrm{C}_{6} \mathrm{H}_{5} \mathrm{O}_{7}$ & $\begin{array}{l}8.5 \\
0.2\end{array}$ & 17.4 & 8.1 & 2.6 \\
\hline $\mathrm{NH}_{2} \mathrm{CONH}_{2}$ & $\begin{array}{l}9.3 \\
8.9\end{array}$ & $\begin{array}{l}2.8 \\
5.2\end{array}$ & $\begin{array}{l}0 \\
8.6\end{array}$ & $\begin{array}{r}2.7 \\
11.3\end{array}$ \\
\hline $\mathrm{KNO}_{3}$ & 9.2 & 5.4 & $\begin{array}{l}8.6 \\
0\end{array}$ & $\begin{array}{l}1.3 \\
10.3\end{array}$ \\
\hline$\left(\mathrm{NH}_{4}\right)_{2} \mathrm{C}_{2} \mathrm{O}_{4} \cdot \mathrm{H}_{2} \mathrm{O}$ & 9.3 & 2.2 & 0 & 0 \\
\hline $\mathrm{H}_{2} \mathrm{NCSNH}_{2}$ & 6.5 & 1.4 & 0 & 0 \\
\hline Peptone & 7. 6 & 11.4 & 0 & 0 \\
\hline Yeast extract & 8: 2 & 10.0 & 0 & 0 \\
\hline Malt extract & 7. 5 & 2.6 & 0 & 6.5 \\
\hline Tryptose & 7.8 & 13.2 & 13.8 & 3.8 \\
\hline Soy bean & 8.2 & 1.4 & 0 & 0 \\
\hline Casamino acids & 8.8 & 11.4 & 12.6 & 5.8 \\
\hline
\end{tabular}


in Table 4. The nitrogen sources produced high extracellular pullulanase were $\mathrm{CH}_{3} \mathrm{COONH}_{4},\left(\mathrm{NH}_{4}\right) \mathrm{H}_{2} \mathrm{PO}_{4},\left(\mathrm{NH}_{4}\right)_{2} \mathrm{HPO}$, and $\mathrm{HCOONH}_{4}$, in decreasing order. On the other hand, $\left(\mathrm{NH}_{4}\right)_{2} \mathrm{SO}_{4}, \mathrm{NH}_{4} \mathrm{Cl}, \mathrm{HCOONH},,\left(\mathrm{NH}_{4}\right) \mathrm{H}_{2} \mathrm{PO}_{4}$ and $\left(\mathrm{NH}_{4}\right)_{2} \mathrm{HPO}_{4}$, also in decreasing order, acted as effective nitrogen sources for production of high intracellular pullulanase. However, $\left(\mathrm{NH}_{4}\right)_{2} \mathrm{HPO}_{4},\left(\mathrm{NH}_{4}\right) \mathrm{H}_{2} \mathrm{PO}_{4}$ and $\mathrm{HCOONH}_{4}$ produced both intra- and extra-cellular pullulanase simultaneously, whereas particularly $\left(\mathrm{NH}_{4}\right)_{2} \mathrm{SO}_{4}$ and $\mathrm{NH}_{4} \mathrm{Cl}$ produced pullulanase more abundantly in the cells and the enzyme was not released from them.

$\mathrm{CH}_{3} \mathrm{COONH}_{4}$ released largely pullulanase from the cells into the culture broth and accumulation of pullulanase in the cells was very small.

From the experimental results obtained above, productivity of pullulanase was not dependent on the final $\mathrm{pH}$ and cell growth using various nitrogen sources.

\section{Effect of nitrogen sources in the absence of calcium carbonate}

The effect of eight nitrogen sources selected on the basis of their effects on intra- and extra-cellular pullulanase production (Table 4), was investigated with the medium free from calcium carbonate (Table 5). The extracellular pullulanase productivity was found to be the highest in case of $\mathrm{CH}_{3} \mathrm{COONH}_{4}$ among the nitrogen sources investigated.

Intracellular pullulanase was accumulated in small quantity in the cells in every case of nitrogen sources.

It appears that if the $\mathrm{pH}$ for the cultivation of the bacteria is lowered below 5.0, the pullulanase production becomes increasingly difficult.

Table 5. Effect of nitrogen source on pullulanase production in the absence of $\mathrm{CaCO}_{3}$.

\begin{tabular}{lcccc}
\hline Nitrogen source & Final pH & $\begin{array}{c}\text { Growth } \\
\text { (O.D. at 660nm) }\end{array}$ & $\begin{array}{c}\text { Pullulanase activity } \\
\text { Intracellular } \\
(\mathrm{D} / \mathrm{ml})\end{array}$ & $\begin{array}{c}\text { Extracellular } \\
\text { (U/ml) }\end{array}$ \\
\hline$\left(\mathrm{NH}_{4}\right)_{2} \mathrm{SO}_{4}$ & 4.0 & 1.8 & 0 & 0 \\
$\mathrm{NH}_{4} \mathrm{Cl}_{3}$ & 4.0 & 2.8 & 0 & 0 \\
$\left(\mathrm{NH}_{4}\right)_{2} \mathrm{HPO}_{4}$ & 5.3 & 9.2 & 0 & 10.0 \\
$\left(\mathrm{NaN}_{4} \mathrm{H}_{2} \mathrm{PO}_{4}\right.$ & 5.2 & 9.4 & 0 & 3.5 \\
$\mathrm{NaNO}_{3}$ & 6.8 & 6.8 & 3.5 & 10.0 \\
$\mathrm{KNO}_{3}$ & 9.1 & 6.8 & 5.4 & 0 \\
$\left(\mathrm{NH}_{4}\right)_{2} \mathrm{C}_{4} \mathrm{H}_{4} \mathrm{O}_{6}$ & 4.7 & 6.8 & 0 & 0 \\
$\mathrm{CH}_{3} \mathrm{COONH}_{4}$ & 8.9 & 11.0 & 5.3 & 53.0 \\
\hline
\end{tabular}

\section{Effect of the concentration of nitrogen sources}

It was revealed that when $\left(\mathrm{NH}_{4}\right)_{2} \mathrm{SO}_{4}$ or $\mathrm{NH}_{4} \mathrm{Cl}$ was used as a nitrogen source of the medium, the cells accumulated much enzyme whereas a good amount of it was released from the cells in case of $\mathrm{CH}_{3} \mathrm{COONH}_{4}$. Therefore, A- and B-media are called as the intra- and extra-cellular enzyme producing medium respectively.

The pullulanase production was investigated by using 0 to $1.2 \%(\mathrm{w} / \mathrm{v})$ $\left(\mathrm{NH}_{4}\right)_{2} \mathrm{SO}_{4}$ in the intracellular enzyme producing medium. As shown in Fig. 1A, the accumulation of the intracellular enzyme was increased by the increase of concentration of $\left(\mathrm{NH}_{4}\right)_{2} \mathrm{SO}_{4}$. Pullulanase was released in a very small quan. 


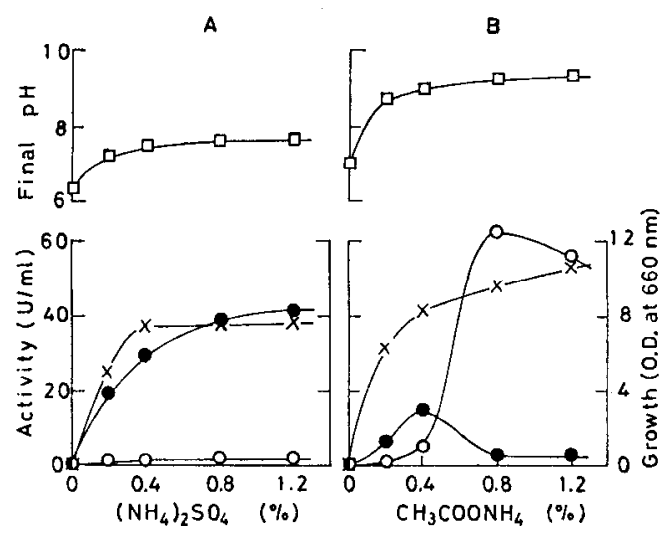

Fig. 1. Effect of the concentration of nitrogen sources on pullulanase production. A: intracellular enzyme producing medium. B: extracellular enzyme producing medium. : intracellular pullulanase activity. $\bigcirc$ :extracellular pullulanase activity. $\mathrm{x}$ : cell growth. $\square: \mathrm{pH}$.

tity in the medium in every case within the concentration investigated. Up to $0.4 \%$ concentration, cell growth was poor and final $\mathrm{pH}$ was changed either in neutral or acidic side.

Then, the pullulanase production was investigated by using 0 to $1.2 \%$ $\mathrm{CH}_{3} \mathrm{COONH}_{4}$ in the extracellular enzyme producing medium. As shown in Fig. $1-\mathrm{B}$, up to $0.5 \%$ concentration, a small amount of pullulanase was produced and the quantity of intracellular enzyme was higher than that of extracellular one. The cell growth was also less. The optimum amount of $\mathrm{CH}_{3} \mathrm{COONH}_{4}$ was $0.8 \%$, the amount higher than this causing a decrease in extracellular pullulanase production. However, the cell growth and final $\mathrm{pH}$ were found to increase by the increase of concentration of $\mathrm{CH}_{3} \mathrm{COONH}_{4}$.

\section{Effect of carbon sources}

The effects of some mono-, di- and poly-saccharides were studied as carbon sources using the intracellular enzyme producing medium (Table 6). Liquefied potato starch showed the highest productivity of intracellular enzyme and then potato starch, though the cells could satisfactorily grow using all the carbon sources except dextran. There was no correlation between productivity of enzyme and final $\mathrm{pH}$.

Pullulanase production was investigated using the same carbon sources in the extracellular enzyme producing medium (Table 7). The final $\mathrm{pH}$ was found to be below 6.0 and the cell growth was poor in case of glucose, galactose and fructose. All of these carbon sources did not cause extracellular enzyme production. Liquefied potato starch was also the most suitable carbon source for extracellular enzyme production. Liquefied starches acted as effective carbon source than raw starches. In these cases, there was correlation between productivity and final $\mathrm{pH}$.

As pullulanase, which hydrolyzes $\alpha-1.6$-glucosidic linkages, could be produced mainly from polysaccharides possessing $\alpha-1.4$ - and 1.6-glucosidic link- 
Table 6. Effect of carbon sources on intracellular pullulanase production.

\begin{tabular}{|c|c|c|c|c|}
\hline \multirow{2}{*}{ Carbon source } & \multirow{2}{*}{ Final $\mathrm{pH}$} & \multirow{2}{*}{$\begin{array}{r}\text { Growth } \\
\text { (O.D. at } 660\end{array}$} & \multicolumn{2}{|c|}{ Pullulanase activity } \\
\hline & & & $\begin{array}{c}\text { Intracellular } \\
(\mathrm{U} / \mathrm{ml})\end{array}$ & $\begin{array}{c}\text { Extracellular } \\
(\mathrm{U} / \mathrm{ml})\end{array}$ \\
\hline Soluble starch & 7.1 & 7.5 & 7.1 & 14.7 \\
\hline Potato starch & 7. 6 & 10.7 & 28.2 & 1.1 \\
\hline Liquefied potato starch & 8.1 & 9.6 & 34.1 & 1.3 \\
\hline Corn starch & 8.2 & 8.8 & 11.8 & 1.4 \\
\hline Liquefied corn starch & 8.2 & 7.2 & 23.1 & 1.5 \\
\hline Sweet potato starch & 8.6 & 8.1 & 5.7 & 0.8 \\
\hline Liquefied sweet potato starch & 8.3 & 5.8 & 6. 2 & 0.4 \\
\hline Wheat starch & 8.2 & 8.7 & 4.3 & 0.6 \\
\hline Liquefied wheat starch & 8.3 & 5.5 & 4.4 & 0.4 \\
\hline Cassava starch & 8.8 & 8.3 & 4.5 & 2.5 \\
\hline Liquefied cassava starch & 8.2 & 6.9 & 24.1 & 2.8 \\
\hline Dextran & 7. 7 & 0.4 & 0 & 0 \\
\hline Pullulan & 8.0 & 9.9 & 5.4 & 1.2 \\
\hline Maltose & 7.9 & 10: 3 & 7.5 & 0.6 \\
\hline Sucrose & 8.1 & 9.8 & 0.5 & 1.1 \\
\hline Lactose & 8.1 & 10.5 & 1.0 & 0.5 \\
\hline Glucose & 8.0 & 11: 3 & 5.0 & $0: 4$ \\
\hline Galactose & 8.3 & 10.5 & 1.2 & 1.6 \\
\hline Fructose & 8.0 & 11.1 & 0 & 0.5 \\
\hline Mannite & 7.8 & 11.5 & 0.7 & 0 \\
\hline
\end{tabular}

Table 7. Effect of carbon sources on extracellular pullulanase production.

\begin{tabular}{|c|c|c|c|c|}
\hline \multirow[b]{2}{*}{ Carbon source } & \multirow{2}{*}{ Final $\mathrm{pH}$} & \multirow{2}{*}{$\begin{array}{l}\text { Growth } \\
\text { (O.D. at } 660\end{array}$} & \multicolumn{2}{|c|}{ Pullulanase activity } \\
\hline & & & $\begin{array}{c}\text { Intracellular } \\
(\mathrm{U} / \mathrm{ml})\end{array}$ & $\begin{array}{c}\text { Extracellular } \\
(\mathrm{U} / \mathrm{ml})\end{array}$ \\
\hline -Soluble starch & 9.1 & 9.5 & 2.2 & 34.8 \\
\hline Potato starch & 9.2 & 12.1 & 9.5 & 4.6 \\
\hline Liquefied potato starch & 9.3 & 10.7 & 3.2 & 58.9 \\
\hline Corn starch & 9.3 & 11.7 & 11: 7 & 0.7 \\
\hline Liquefied corn starch & 9.2 & 10. 0 & 1.7 & 45.7 \\
\hline Sweet potato starch & 9.3 & 13.0 & 5.3 & 0.9 \\
\hline Liquefied sweet potato starch & 9.4 & 8.9 & 1.5 & 29.8 \\
\hline Wheat starch & 9.5 & 13.9 & 11.1 & 0.6 \\
\hline Liquefied wheat starch & 9.4 & a. 1 & 1.3 & 22.9 \\
\hline $\begin{array}{l}\text { Cassava starch } \\
\text { Stall }\end{array}$ & 9.3 & 12.5 & 4.0 & 0.9 \\
\hline Liquefied cassava starch & 9.4 & 9.7 & 2.4 & 57.6 \\
\hline Dextran & 4.0 & 9.4 & 0 & 0 \\
\hline Pullulan & 9.2 & 12: 1 & 2.0 & 8.6 \\
\hline Maltose & 9.3 & 11.4 & 1.2 & 9.7 \\
\hline Sucro & 9.3 & 10.3 & 0.5 & 0.9 \\
\hline Lacto & 9.2 & 12.4 & 0.5 & 1.0 \\
\hline Glucose & 5.5 & $\begin{array}{r}0.4 \\
0.4\end{array}$ & 0 & 0 \\
\hline $\mathrm{Ga}$ & 6.0 & 0.2 & 0 & 0 \\
\hline Fructose & 5.7 & 0.6 & & 0 \\
\hline Mannite & $9: 2$ & 11: 1 & 1.0 & 1.0 \\
\hline
\end{tabular}

ages, it is considered that pullulanase is an "induced enzyme".

\section{Effect of the concentration of liquefied potato starch}

The effects of various concentrations of liquefied potato starch on the intra- and extra-cellular pullulanase production are shown in Fig. 2. The cell growth was increased by the increase of concentration of liquefied potato starch. The optimum concentration of liquefied potato starch for the intraand extra-cellular enzyme production were found to be 1.25 and $1.5 \%$, respec- 


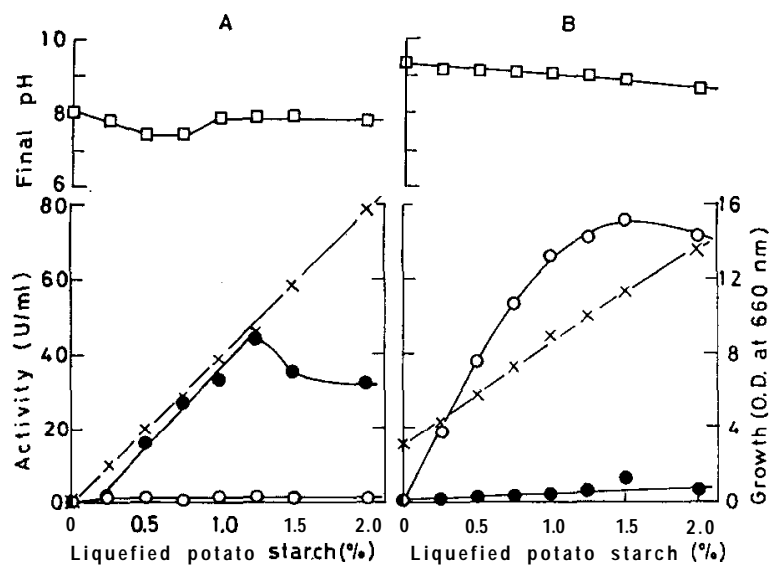

Fig. 2. Effect of the concentration of liquefied potato starch on pullulanase production. Symbols same as in Fig. 1.

tively (Fig. 2-A and B).

Effect of the concentration of dipotassium hydrogen phosphate

The results on the effect of concentration of $\mathrm{K}_{2} \mathrm{HPO}_{4}$ are shown in Fig. 3 . Above $0.05 \%$, there was almost no variation of cell growth. The optimum concentrations of $\mathrm{K}_{2} \mathrm{HPO}_{4}$ for intra- and extra-cellular enzyme production were 0.1 and $0.2 \%$, respectively. At higher concentrations above $\mathbf{0} . \mathbf{1} \%$, the intracellular enzyme production was found to decrease very sharply (Fig. 3-A).

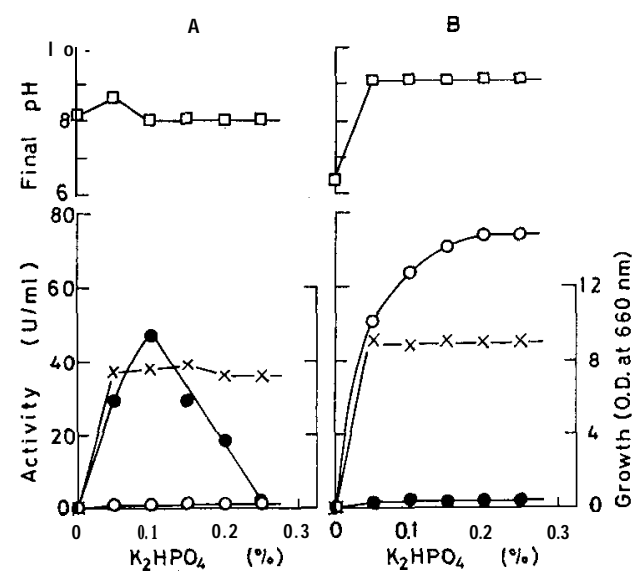

Fig. 3. Effect of the concentration of $\mathrm{K}_{2} \mathrm{HPO}_{4}$ on pullulanase production. Symbols same as in Fig. 1.

\section{Effect of the concentration of magnesium sulfate}

The results on the effect of concentration of $\mathrm{MgSO}_{4} \cdot 7 \mathrm{H}_{2} \mathrm{O}$ are shown in Fig. 4. Above $0.025 \%$, the cell growth and final $\mathrm{pH}$ were found to be approximate- 


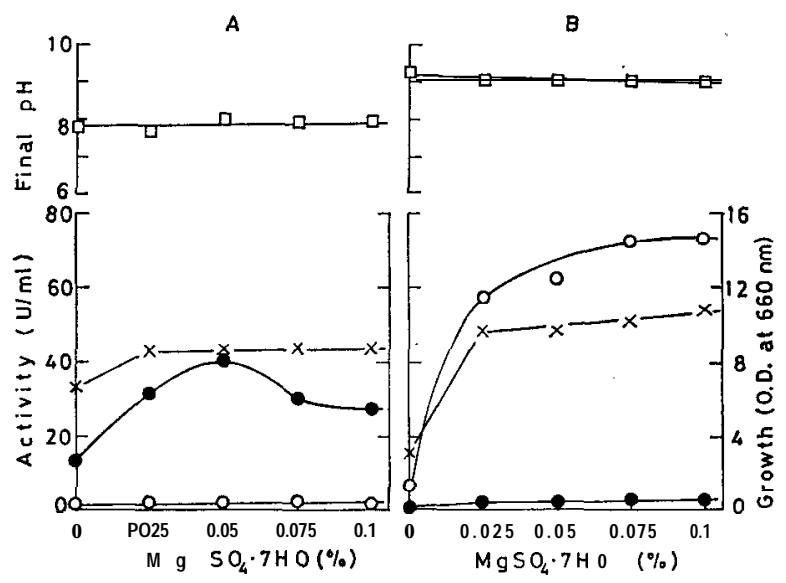

Fig. 4. Effect of the'concentration of $\mathrm{MgSO}_{4} \cdot 7 \mathrm{H}_{2} \mathrm{O}$ on pullulanase production. Symbols same as in Fig. 1.

ly constant. The most favourable concentrations of $\mathrm{MgSO}_{4} \cdot 7 \mathrm{H}_{2} \mathrm{O}$ for the intraand extra-cellular enzyme production were 0.05 and $0.075 \%$, respectively.

\section{Effect of the concentration of potassium chloride}

As shown in Fig. 5, pullulanase production, cell growth and final $\mathrm{pH}$ did not vary within the concentrations investigated. Therfore, it does not seem to be an essential component for intra- and extra-cellular pullulanase formation.

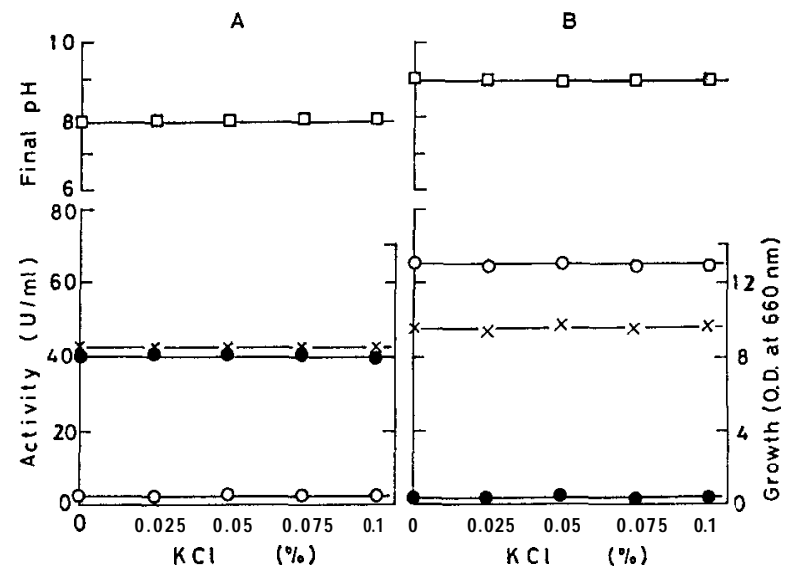

Fig. 5. Effect of the concentration of $\mathrm{KC} 1$ on pullulanase production. Symbols same as in Fig. 1.

\section{Effect of the concentration of peptone}

The results on the effect of concentration of peptone are shown in Fig. 6. Cell growth and final $\mathrm{pH}$ did not vary in case of intracellular enzyme produc. 


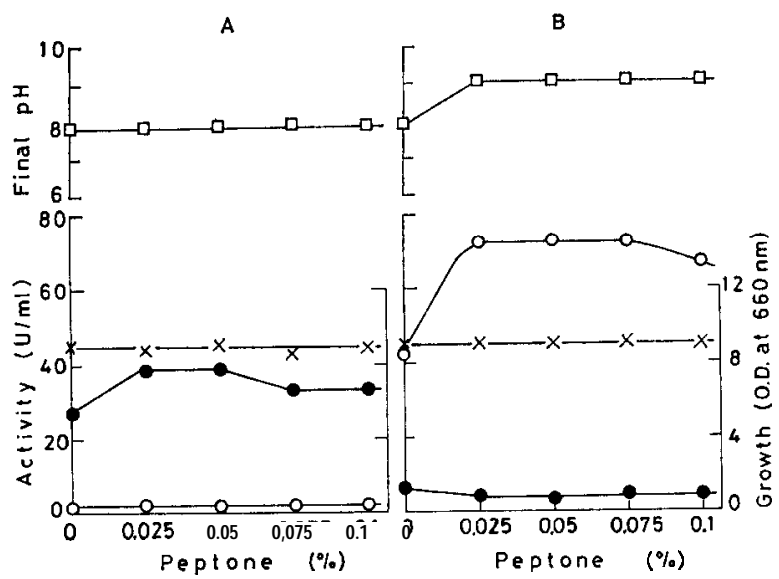

Fig. 6. Effect of the concentration of peptone on pullulanase production. Symbols same as in Fig. 1.

tion. The optimum concentration of peptone for the intra- and extra-cellular enzyme production were $0.025-0.05$ and $0.025-0.075 \%$, respectively.

\section{Effect of the concentration of ferrous sulfate}

The pullulanase production was investigated using 0 to $0.04 \% \mathrm{FeSO}_{4} \cdot 7 \mathrm{H}_{2} \mathrm{O}$ in the intra- and extra-cellular enzyme producing media. The results are shown in Fig. 7. In the intracellular enzyme producing medium, final $\mathrm{pH}$ was scarcely varied but the amount of intracellular pullulanase was fairly varied (Fig. 7-A). The most suitable concentration of $\mathrm{FeSO}_{4} \cdot 7 \mathrm{H}_{2} \mathrm{O}$ was $0.02 \%$.

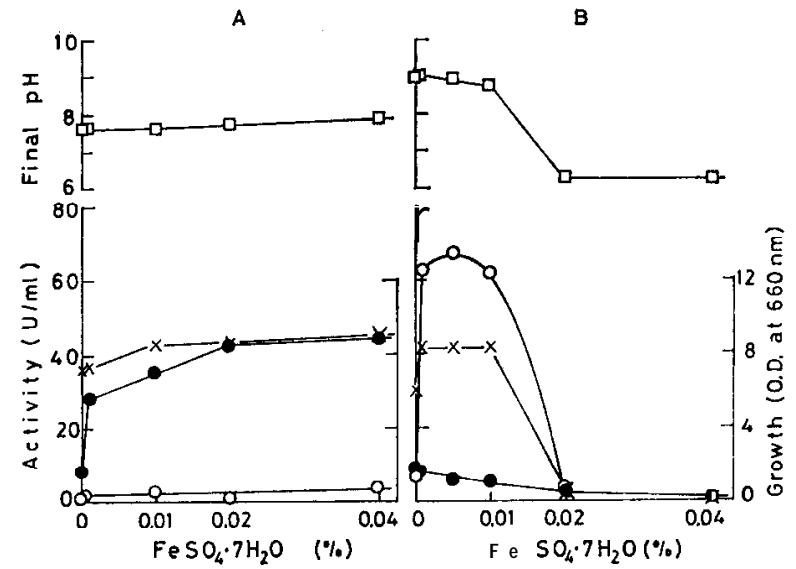

Fig. 7. Effect of the concentration of $\mathrm{FeSO}_{4} \cdot 7 \mathrm{H}_{2} \mathrm{O}$ on pullulanase production. Symbols same as in Fig. 1.

In the extracellular enzyme producing medium, the productivity of extra- 
cellular pullulanase, final $\mathrm{pH}$ and bacterial growth were greatly varied (Fig. 7-B). The optimum concentration of $\mathrm{FeSO}_{4} \cdot 7 \mathrm{H}_{2} \mathrm{O}$ was $0.005 \%$. At higher concentrations above $0.02 \%$, the final $\mathrm{pH}$ decreased to acidic side, the cells could hardly grow and consequently pullulanase production did not occur. It seems that special attention should be paid to the content of $\mathrm{FeSO}_{4} \cdot 7 \mathrm{H}_{2} \mathrm{O}$ particularly for the extracellular enzyme production.

From the facts described above, it is clear that the intracellular pullulanase production by this bacteria could not be converted into extracellular one and vice versa by using these components (liquefied potato starch, dipotassium hydrogen phosphate, magnesium sulfate, peptone and ferrous sulfate) at various concentrations.

\section{Effect of the concentration of calcium carbonate}

In this experiment, $\mathrm{CaCO}_{3}$ was added to both media in the range of 0 to $1.5 \%$ although $\mathrm{CaCO}_{3}$ had not been used before in the extracellular enzyme producing medium. The results are shown in Fig. 8. When $\mathrm{CaCO}_{3}$ was omitted from the intracellular enzyme producing medium, final $\mathrm{pH}$ and cell growth were decreased and the intracellular pullulanase production did not occur (Fig. 8-A).
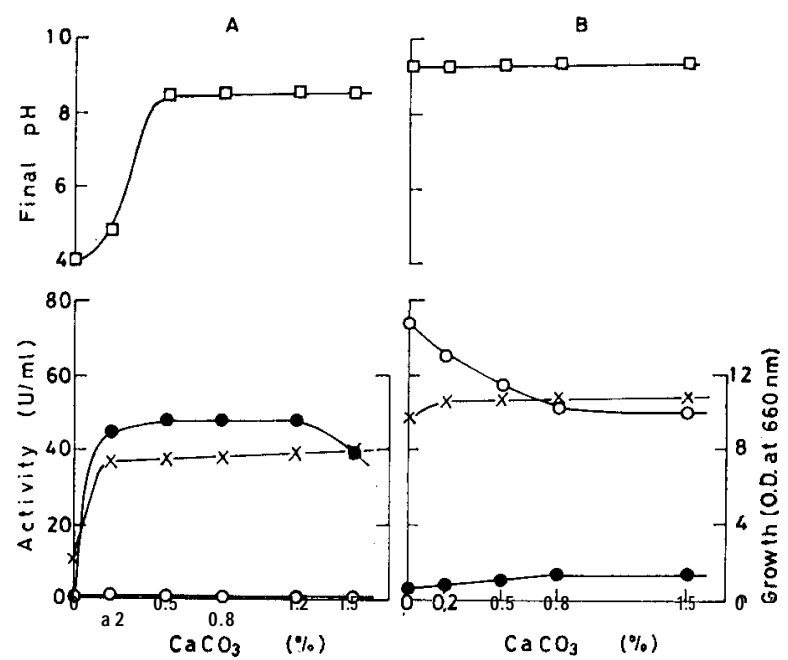

Fig. 8. Effect of the concentration of $\mathrm{CaCO}_{3}$ on pullulanase production. Symbols same as in Fig. 1.

On the other hand, the extracellular pullulanase production was found to decrease gradually by the increase of concentration of $\mathrm{CaCO}_{3}$ but the final $\mathrm{pH}$ and cell growth remained almost unchanged. In the absence of $\mathrm{CaCO}_{3}$, the extracellular pullulanase was produced maximaly.

\section{Effect of pH}

The initial $\mathrm{pH}$ of the intracellular pullulanase producing medium in the presence of $\mathrm{CaCO}_{3}$ was adjusted at various $\mathrm{pH}$ by adding $0.1 \mathrm{~N}$ HCI or $\mathrm{NaOH}$. 


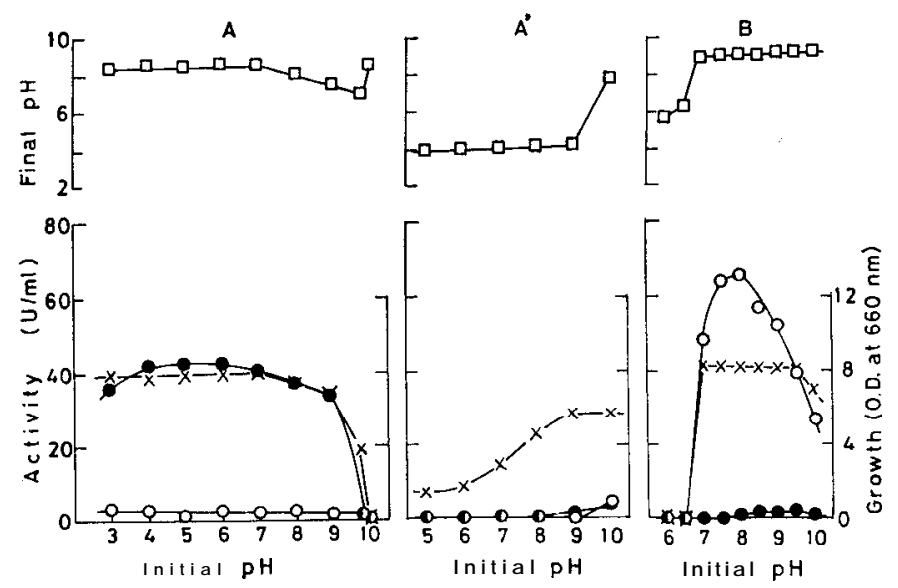

Fig. 9. Effect of initial $\mathrm{pH}$ on pullulanase production. A : intracellular enzyme producing medium in the presence of $\mathrm{CaCO}_{3}$. In this case, initial $\mathrm{pH}$ was the value before adding of $\mathrm{CaCO}_{3}$. A': intracellular enzyme producing medium in the absence of $\mathrm{CaCO}_{3}$. B : extracellular enzyme producing medium. Other symbols same as in Fig. 1.

At the wide range between $\mathrm{pH} 3$ and 9, the cell growth was rich and the intracellular pullulanase activity was high (Fig. 9-A). At $\mathrm{pH} 10$, there was no growth and enzyme formation.

Then enzyme productivity was investigated in the intracellular pullulanase producing medium in the absence of $\mathrm{CaCO}_{3}$ (Fig. 9-A'). Up to initial pH 9, the growth was poor, final $\mathrm{pH}$ became low at around 4 and there was no enzyme formation. At initial $\mathrm{pH} \mathrm{10,} \mathrm{both} \mathrm{enzymes} \mathrm{could} \mathrm{be} \mathrm{hardly} \mathrm{produced} \mathrm{al-}$ though the final $\mathrm{pH}$ became at 8.0. The results suggested that the pullulanase production was not performed with the medium in the absence of $\mathrm{CaCO}_{3}$ whatever initial $\mathrm{pH}$ was. A delicate $\mathrm{pH}$-control invivo during cultivation might be concerned in the biosynthesis of pullulanase. $\mathrm{CaCO}_{3}$ was an essential component for the intracellular enzyme production.

On the other hand, in case of the extracellular enzyme production, when the initial $\mathrm{pH}$ was on acidic side, the bacterial growth was poor and final $\mathrm{pH}$ remained at acidic side (Fig. 9-B). The enzyme production was nil. If the initial $\mathrm{pH}$ was at alkaline side, the final $\mathrm{pH}$ of the culture broth always reached at about 8.5. The optimum initial $\mathrm{pH}$ for the extracellular enzyme production was 8.0.

\section{Role of each component in pullulanase formation}

On the basis of the experimental data, some essential components in the pullulanase producing media and their roles were considered in some detail. Fig. 10 shows the amount of pullulanase (activity), final $\mathrm{pH}$ and cell growth when only one component was lacked from the basal medium. In the intracellular pullulanase production, peptone was not concerned in the ceil growth but the amount of pullulanase was decreased by $30 \%$ in the absence of this 


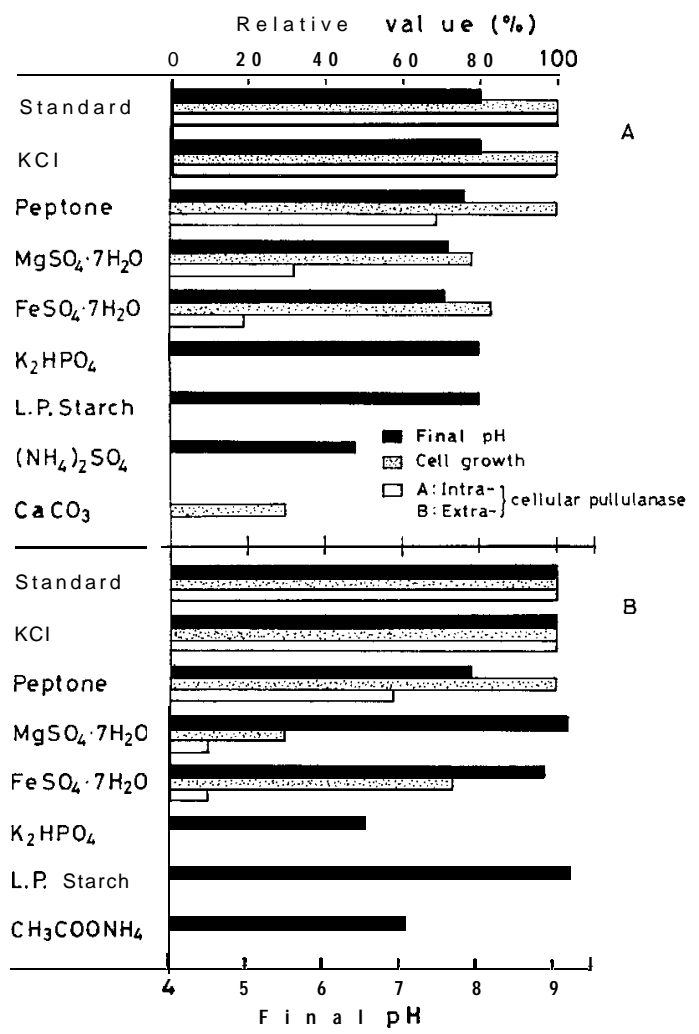

Fig. 10. Effect of lacking of medium component on pullulanase production. A: intracellular enzyme producing medium. B: extracellular enzyme producing medium.

compound (Fig. 10-A). The intracellular pullulanase production was found to be more decreased than cell growth by $\mathrm{MgSO}_{4}$ and $\mathrm{FeSO}_{4} \cdot 7 \mathrm{H}_{2} \mathrm{O}$. In the absence of $\mathrm{K}_{2} \mathrm{HPO}_{4}$, liquefied potato starch or $\left(\mathrm{NH}_{4}\right)_{2} \mathrm{SO}_{4}$, the bacteria could not grow at all and pullulanase was not formed. It was found that all other components except $\mathrm{KCl}$ played important roles for pullulanase production.

The effects resulted from lacking of components for extracellular enzyme production were almost similar to those of the intracellular enzyme production (Fig. 10-B).

The optimum medium for pullulanase production and the time course of cultivation

The optimum media for intra- and extra-cellular enzyme production is given in Table 8 . The time course of cell growth, $\mathrm{pH}$ and pullulanase production were investigated using the optimum media (Figs. 11 and 12). In the intracellular pullulanase producing medium, residual sugar of carbon source had been consumed within $18 \mathrm{hr}$ (Fig. 11). The pH-value of the culture broth once decreased to 6.2, and then increasd gradually around 8.0. Intracellular 
Table 8. The optimum medium for pullulanase production.

\begin{tabular}{|c|c|}
\hline Component & Content $(\%, w / v)$ \\
\hline \multicolumn{2}{|c|}{ Intracellular pullulanase producing medium } \\
\hline Liquefied potato starch & 1. 25 \\
\hline$\left(\mathrm{NH}_{4}\right)_{2} \mathrm{SO}_{4}$ & 0.8 \\
\hline $\mathrm{K}_{2} \mathrm{HPO}_{4}$ & 0.1 \\
\hline $\mathrm{MgSO}_{4} \cdot 7 \mathrm{H}_{2} \mathrm{O}$ & 0.05 \\
\hline Peptone & 0.03 \\
\hline $\mathrm{FeSO} \cdot 7 \mathrm{H}_{2} \mathrm{O}$ & 0.02 \\
\hline $\mathrm{CaCO}_{3}$ & 0.5 \\
\hline Initial pH & 7.0 \\
\hline \multicolumn{2}{|c|}{ Extracellular pullulanase producing medium } \\
\hline Liquefied potato starch & 1.5 \\
\hline $\mathrm{CH}_{3} \mathrm{COONH}_{4}$ & 0.8 \\
\hline $\mathrm{K}_{2} \mathrm{HPO}_{4}$ & 0.2 \\
\hline $\mathrm{MgSO}_{4} \cdot 7 \mathrm{H}_{2} \mathrm{O}$ & 0.075 \\
\hline Peptone & 0.03 \\
\hline $\mathrm{FeSO}_{4} \cdot 7 \mathrm{H}_{2} \mathrm{O}$ & 0.005 \\
\hline Initial $\mathrm{pH}$ & 8.0 \\
\hline
\end{tabular}

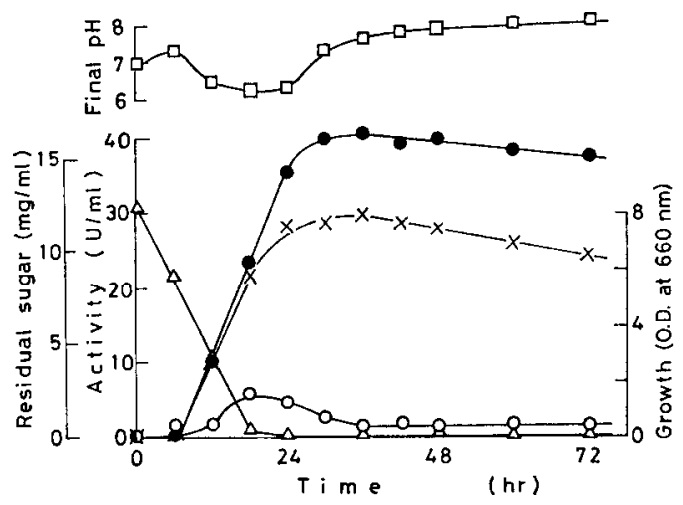

Fig. 11. Time course of intracellular pullulanase production. $\triangle$ : residual sugar. Other symbols same as in Fig. 1.

pullulanase production was found to increase after $6 \mathrm{hr}$ and became nearly parallel to the bacterial growth. The bacterial growth and intracellular pullulanase production occurred maximum at $36 \mathrm{hr}$, then these were decreased slowly and linearly. The extracellular pullulanase was hardly released into the medium during the cultivation.

In the extracellular enzyme producing medium, residual sugar were consumed within $36 \mathrm{hr}$ (Fig. 12). The pH-value once decreased slightly and soon increased gradually up to 9 . Pullulanase production was preceded by the bacterial growth. The pullulanase began to be accumulated in the cells after 24 $\mathrm{hr}$ and to be released soon outside the cells. The time of the maximum ac- 


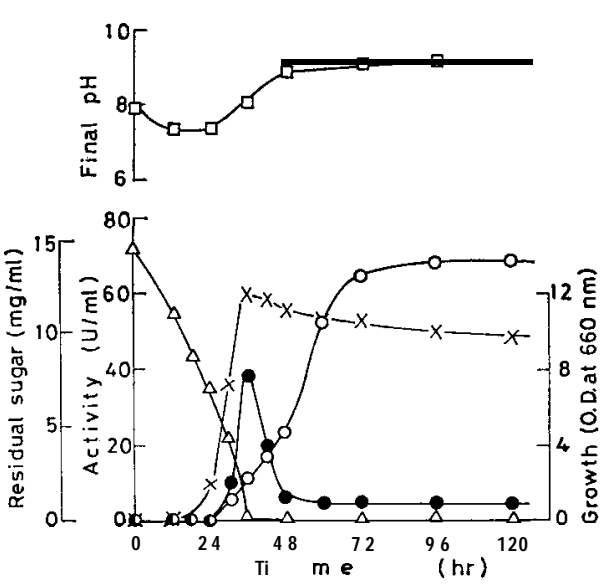

Fig. 12. Time course of extracellular pullulanase production. Symbols same as in Fig. 11.

cumulation of intracellular pullulanase almost corresponded to that of the maximum cell growth. As soon as the growth began to decrease, the release of intracellular pullulanase was speeded up rapidly. The maximum of extracellular pullulanase production occurred at $96 \mathrm{hr}$, and then its quantity remained the same.

\section{ACKNOWLEDGEMENT}

The authors wish to thank Mr. S. Kudb of their laboratory for his assistance.

\section{REFERENCES}

Abdullah. M., B. J. Chatley, E. Y. C. Lee, J. Robyt, K. Wallenfels and W. J. Whelan 1966 The mechanism of carbohydrase action II. Pullulanase, an enzyme specific for the hydrolysis of alpha-1. 6-bonds in amylaceous oligo- and polysaccharides. Cereal Chem., $43: 111-118$

Abdullah, M. and D. French 1970 Substrate specificity of pullulanase. Arch. Biochem. Biophys., $137:$ 483-493

Drummond, G. S., E. E. Smith and W. J. Whelan 1969 Mechanism of action of pullulanase. FEBS Letters, $5: 85-88$

Eisele, B., I. R. Rached and K. Wallenfels 1972 Molecular characterization of pullulanase from Aerobacter aerogenes. Eur. J. Biochem.. 26: 62-67

Fujio, Y., M. Shiosaka and S. Ueda 1970 Isoamylase production by Aerobacter aerogenes (1) Effect of nitrogen source. J. Ferment. Technol., 48: 8-13 (in Japanese with English summary)

Hobson, P. N., W. J. Whelan and S. Peat 1951 The enzymic synthesis and degradation of starch XIV. R-enzyme. J. Chem.Soc., 1951: 1451-1459

Kobayashi, T. and B. Maruo 1949 Studies on the enzymic formation and degradation of starch Part I. Examinations on the amylosynthease (1) and (2). Nippon Nogei Kagaku 
Kaishi (J. Agr. Chem. Soc.Japan), 23: 115-123

Maruo, B. and T. Kobayashi 1951 Enzymic scission of the branch links in amylopectin. Nature, $167: 606-607$

Mercier, C., B. M. Frantz and W. J. Whelan 1972 An improved purification of cell-bound pullulanase from Aerobacter aerogenes. Eur. J. Biochem., 26: I-9

Nelson, N. 1944 A photometric adaptation of the Somogyi method for the determination of glucose. J. Biol. Chem., 153: 375-380

Ohba, R., H. Chaen, S. Hayashi and S. Ueda 1978 Immobilization of Streptomyces flavochrogenes pullulanase on tanic acid and TEAE-cellulose. Biotechnol. Bioeng., 20: 665-676

Ohba, R. and S. Ueda 1973 Purification, crystallization and some properties of intracellular pullulanase from Aerobacter aerogenes. Agric. Biol. Chem., 37: 2821-2826

Ohba, R. and S. Ueda 1975 Some properties of crystalline extra- and intra-cellular pullulanase from Aerobacter aerogenes. Agric. Biol. Chem.. 39: 967-972

Ohba, R. and S. Ueda 1980 Production of maltose and maltotriose from starch and pullulan by an immobilized multienzyme of pullulanase and $\beta$-amylase. Biotechnol Bioeng., 22 : 1937-1954

Somogyi, M. 1945 A new reagent for the determination of sugars. J.Biol. Chem., 160: 61-68

Ueda, S., K. Fujita, K. Komatsu and Z. Nakashima 1963 Polysaccharide produced by the genus Pullularia I. Production of polysaccharide by growing cells. Appl.Microbiol., 11: 211-215

Ueda, S. and R. Ohba 1972 Purification, crystallization and some properties of extracellu. lar pullulanase from Aerobacter aerogenes. Agric. Biol. Chem.. 36: 2381-2391

Wallenfels, K., H. Bender and I. R. Rached 1966 Pullulanase from A erobacter a erogenes; production in a cell-bound state. Purification and properties of the enzyme. Biochem. Biophys. Res. Comm., 22: 254-261

Wallenfels, K. und I. R. Rached 1966 Kristallisation und Stereospezifität der Pullulanase aus Aerobacter aerogenes. Biochem. Z.. 344: 524-526

Wallenfels, K., I. R. Rached und F. Hucho 1969 Klassifizierung der Pullulanase als Exoenzyme mit Hilfe der Gaschromatographie. Eur. J. Biochem., 7: 231-233 